\title{
The Complete Works of
}

\section{Robert Browning}

WITH VARIANT READINGS AND ANNOTATIONS

ROMA A. KING, JR., GENERAL EDITOR

This edition which will be in thirteen volumes traces Robert Browning's poetic growth and his life-long revisions by presenting all his known works with variant readings and annotations.

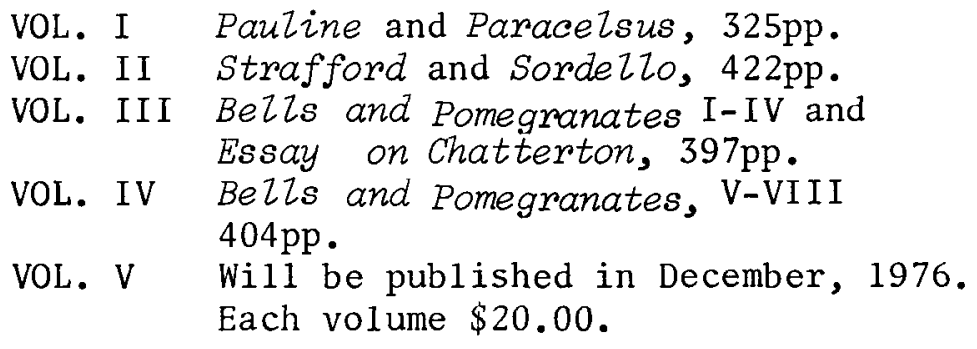

\section{Other Browning Books:}

THE FOCUSING ARTIFICE: THE POETRY OF ROBERT $B R O W V I V G$, Roma A. King, Jr., 234pp, \$9.00

DIARY BY ELIZABETH BARRETT BROWIING, Philip Kelly and Ronald Hudson, eds., 495pp, \$12.00.

THE VARIANCE AND THE UNITY: A STUDY OF BROWNING'S COMPLEMENTARY POEMS, William E. Harrold, $245 \mathrm{pp}, \$ 9.00$.

WRITERS AND THEIR BACKGROUND: ROBERT BROWINING, Isobel Armstrong, ed., 250pp, $\$ 10.00$ Cloth/ $\$ 3.45$ Paper.

\section{Ohio University Press}




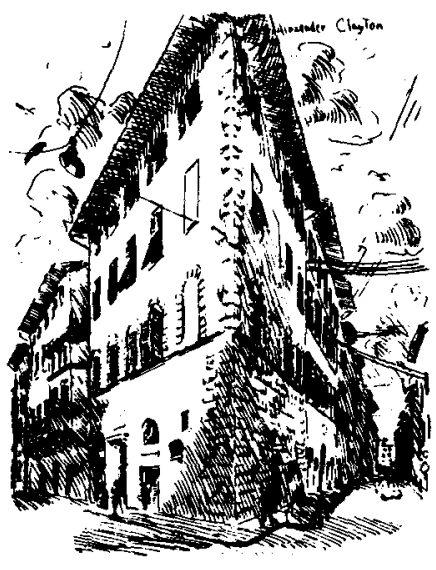

"There was something about this room that seemed to make it a proper and especial haunt for poets," wrote Kate Field, the Brownings' American friend, of their drawing room at Casa Guidi. Today the Browning Institute has made their Florentine apartment open once more to visitors and is planning to restore it as a museum and study center. By joining the Browning Institute, you can contribute to this important undertaking. Members paying $\$ 15$ or more in dues receive a free copy of Browning Institute Studies, and all members are placed on the mailing list of Through Casa Guidi Windows: The Bulletin of the Browning Institute. In addition, members are entitled to discounts on other titles published by the Institute.

The Browning Institute is a nonprofit organization chartered in the State of New York. In order to achieve its goals of restoring Casa Guidi and publishing significant Browning scholarship, the Institute needs your dues and contributions.

\section{SCHEDULE OF DUES}

Life membership

Sponsor

Contributing

Sustaining

REGULAR

Library

Student

Foreign

Browning Societies and cultural organizations

Corporate
$\$ 1000$

$\$ 250$

$\$ 100$

$\$ 30$

$\$ 15$

$\$ 15$

$\$ 3$

$\$ 5$

$\$ 1$ per active member

$\$ 250$ (minimum)

Send dues and contributions to: The Browning Institute, Inc., Box 2983, Grand Central Station, New York, N.Y. 10017. 
William S. Peterson, Robert and Elizabeth Barrett Browning: An Annotated Bibliography, 1951-1970. 1974. 224 pages. List price, $\$ 25.00$; members' price, $\$ 18.75$.

Peter N. Heydon and Philip Kelley, editors, Elizabeth Barrett Browning's Letters to Mrs. David Ogilvy. 1973. 256 pages. List price, $\$ 7.95$; sale price, $\$ 4.75$.

Browning Institute Studies, Volume 1 (1973). 226 pages. List price, $\$ 18.75$; members' price, $\$ 10.00$.

Browning Institute Studies, Volume 2 (1974). 240 pages. List price, $\$ 18.75$; members' price, $\$ 10.00$.

Maisie Ward, The Tragi-Comedy of Pen Browning. 1972. 192 pages, including 32 pages of illustrations. List price, $\$ 8.50$; sale price, $\$ 4.25$.

\section{ALSO AVAILABLE}

Emily Blanchard Hope, "Saving Casa Guidi." Reprinted from Browning Institute Studies, 1 (1973). 30 pages. List price, $\$ 3.00$; members' price, $\$ 1.50$.

Peter N. Heydon, "Whatever Became of the Pauline Poet?" Reprinted from Browning Society Notes, 3 (March 1973). 22 pages. List price, \$3.00; members' price, $\$ 1.50$.

Edward R. Moulton-Barrett, Talking about the Barretts: A Prologue and an Epilogue to the Play 'The Barretts of Wimpole Street'. A lecture given to the Browning Society meetings in New York and Boston, October 1973. 16 pages. List price, $\$ 2.50$; members' price, $\$ 1.25$.

William S. Peterson, Interrogating the Oracle: A History of the London Browning Society. 1969. 288 pages. List price, $\$ 10.00$; sale price, $\$ 4.40$.

\section{The Browning Institute, Inc.}

Box 2983, Grand Central Station, New York, N.Y. 10017

9, Lakenheath, Southgate, London N14 4RJ

Piazza S. Felice 8, Florence 50125 